Article

\title{
Exploring Organizational Sustainability of Industry 4.0 under the Triple Bottom Line: The Case of a Manufacturing Company
}

\author{
Alessio Maria Braccini $(\mathbb{D}$ and Emanuele Gabriel Margherita * $\mathbb{D}$ \\ Department of Economics, Engineering, Society and Business, Università degli Studi della Tuscia, \\ via del Paradiso 47, 01100 Viterbo (VT), Italy; abraccini@unitus.it \\ * Correspondence: emargherita@unitus.it
}

Received: 31 October 2018; Accepted: 19 December 2018; Published: 21 December 2018

check for updates

\begin{abstract}
There is an increasing interest in sustainability practices for organizations. Organizations act sustainably when they support the three dimensions \of the triple bottom line. Industry 4.0 (I40) promises to afford organizations to act sustainably. However, few empirical pieces of research targeted the impact of I40 on the social, economic, and environmental dimensions of sustainability. Our investigation considered the adoption of I40 in a manufacturing company which we analyzed as a single case study. We describe the level of I40 adoption and the process through which the unit has adopted them. Our case confirms that I40 applications support the triple bottom line through the improvement of productivity and product quality (economic), continuous energy consumption monitoring (environmental), and safer work environment and less intense work-load and job enrichment (social). We contribute to the literature by identifying two trajectories of interaction among the three dimensions of the triple bottom line in the shift from a traditional manufacturing company to a knowledge-intense organization. In the trajectories found, the three dimensions of sustainability influence and reinforce each other.
\end{abstract}

Keywords: Industry 4.0; organizational sustainability; triple bottom line; smart factory

\section{Introduction}

Owing to the rising global population, climate change, pollution, and the scarcity of natural resources, sustainability has become a fundamental orientation for today's organizations [1]. Organizations act sustainably when they simultaneously support all the dimensions of the triple bottom line (TBL)_ecological, social, and economic [2,3]. Sustainability is one of the drivers of Industry 4.0 (henceforth I40), an industry initiative that through the adoption of digital technologies on the assembly line is changing traditional factories into smart factories [4,5]. While research has addressed the environmental sustainability of I40 applications [6,7], researchers paid little attention to how I40 simultaneously addresses all the dimensions of the triple bottom line [8,9]. Further research is also needed to analyze the " ... interplaying and partly conflicting relationship of the triple bottom line dimensions ..." in the context of I40 [10].

Our investigation considers an in-depth single case study on a manufacturing organization producing sanitary ceramics in a smart factory adopting I40 technologies. Analyzing this case, we explore the trajectories of interaction among I40 technologies and the TBL dimensions, answering the following research questions: (i) "How does I40 support the sustainability dimensions in the TBL?"; and (ii) "Which interactions among the three dimensions does I40 support?"

The remainder of the article is organized as follows. Section 2 is devoted to the related literature regarding organizational sustainability and I40. The section also highlights the current gaps in the 
investigations of sustainability in I40. Section 3 introduces the research design. Section 4 illustrates the single case study analysis. Section 5 illustrates the results of the case analysis discussing them regarding sustainability and the interaction among the TBL dimensions and I40. The article concludes in Section 6, proposing implications both for research and practice.

\section{Related Literature}

Our work is framed within the concept of sustainability and develops on the literature discussing I40 applications, and the sustainability potential of I40 applications.

\subsection{Sustainability}

The United Nations World Commission on Environment and Development first introduced the sustainability concept in 1987. In that year, the commission defined sustainability as an economic development model that allows to "meet the needs of the present generation without compromising the ability of future ones to meet their own needs" [11]. Sustainability is a multi-dimensional concept encompassing environmental, social, and economic dimensions. Such dimensions form the TBL view of sustainability (as shown in Figure 1) [2,3].

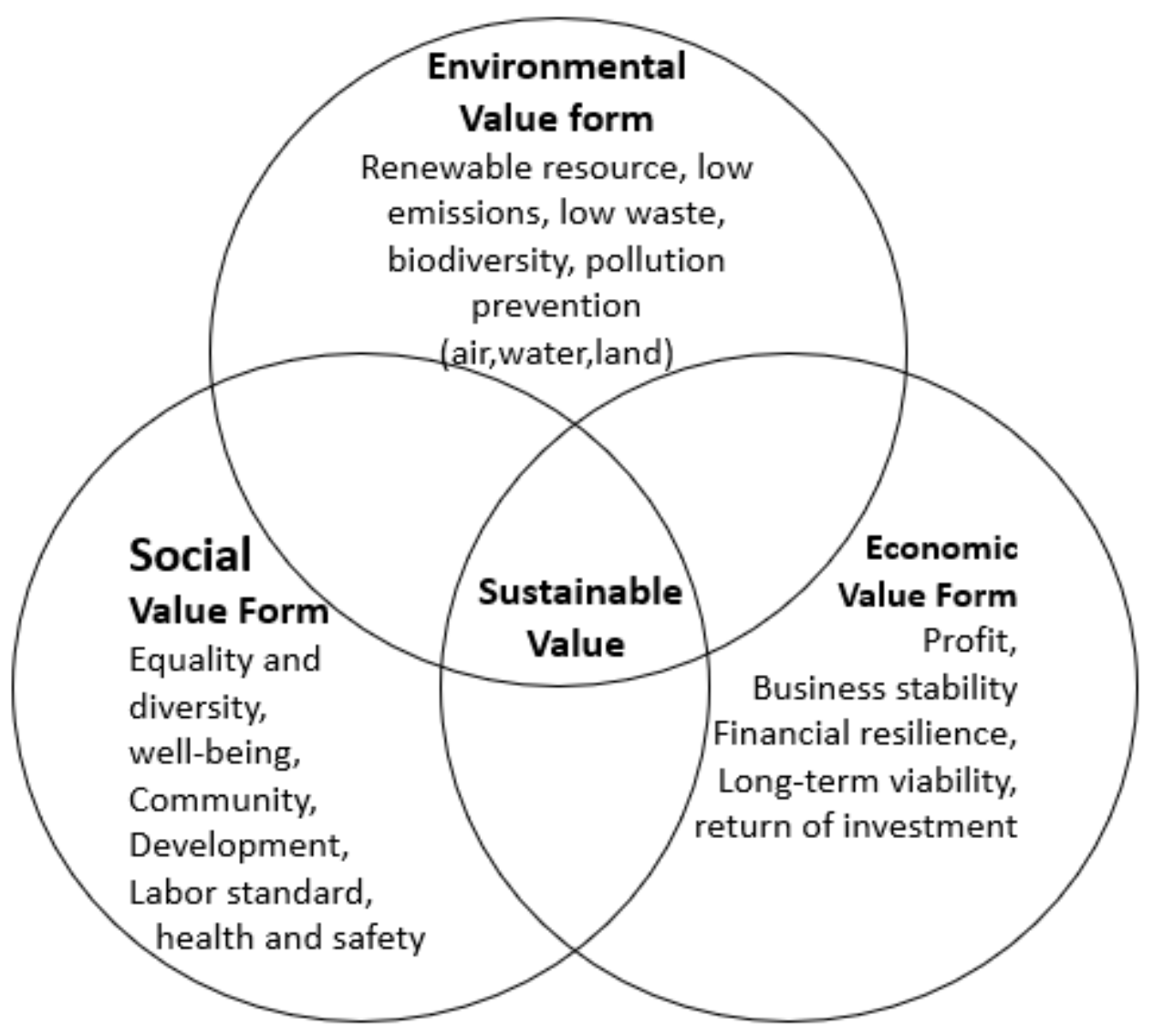

Figure 1. The triple bottom line [12].

The environmental dimension of the TBL focuses on the compatibility between the trend of use and renewal of resources in nature. Referring to organizations, this dimension is manifest in the attitude of consuming just the natural resources that can be reproduced from nature, as well as producing emissions that can be absorbed naturally by the existing ecosystem. This dimension is achievable through recycling and regeneration of resources, redesign of processes and products to minimize resource usage, replacement of non-renewable with renewable resources, and adoption of models of the circular economy $[13,14]$. 
The social dimension of the TBL refers to the organizational attitude to preserve and develop human and social capital of communities within which organizations operate to create value [15]. Social sustainability encompasses aspects like job satisfaction, quality of life, social integration in communities, solidarity, equity and justice in the distribution of goods and services, and equal opportunities in education $[10,16]$.

Lastly, the economic dimension of the TBL refers to the organizational attitude to create value and to balance costs and revenues in the production and distribution of goods and services [17]. The economic dimension of the TBL is concerned with economic and financial performance dimensions of the organization.

These three dimensions interact, overlap, and sometimes conflict. As a matter of example, environmental sustainability could be detrimental to economic sustainability due to the extra investments needed for cleaner production processes. However, organizations need to act holistically to pursue all of them. Each dimension represents a necessary, but not sufficient condition for achieving sustainability: when organizations do not support one of these dimensions, they do not act sustainably $[12,17,18]$. Even though organizations mostly succeed in having synergies between the environmental and the economic dimensions of sustainability, they are still struggling to address the TBL $[10,19]$.

\subsection{Industry 4.0}

I40 is an initiative target at innovating production processes in industries which promises to improve sustainability in organizations. I40 applications employ a mix of leading-edge technologies to innovate assembly lines $[4,5,7]$ :

- Internet of Things (IoT): when we connect machines equipped with sensors and actuators to the internet, we have the IoT. Internet-connected machines can then generate, process, and communicate data in real-time, either to humans or to other machines.

- Robotics: robots are devices that can autonomously perform gestures or movements. Robots can be mechanical arms or self-moving machines. Robots are designed and programmed to perform any desired manipulation tasks (e.g., modeling, welding, gripping, spinning). Robots can be autonomous in their operation, or collaborative with humans.

- Big Data and analytics: this term indicates the overwhelming and unstructured amount of data generated by I40 technologies within the organization. These data are stored on servers through cloud computing technologies [20], and are analyzed with business intelligence, machine learning, and analytics software.

- Cloud computing: it is a set of technologies that offer organizations of IT infrastructures capabilities as a service through the Internet. Cloud computing promises several advantages concerning costs reduction, scalability, and flexibility [21].

- Additive manufacturing: it is commonly also called 3D printing. Additive manufacturing allows producing high-quality physical objects by adding material rather than by mechanically removing material from a solid block. Additive manufacturing can be used with a wide range of different materials (e.g., plastics, metals, composite materials).

In I40 these technologies are used on the assembly line to form cyber-physical systems, where they generate real-time data about the actions performed on production processes and make these data available within the organization [22]. These technologies are used to create advanced manufacturing solutions of modular and interconnected systems that offer great flexibility and performance.

Several scholars pointed at I40 as a means for organizations to support the TBL and explored how I40 support individual dimensions of sustainability. I40 improves organizational productivity and ameliorate work environments passing part of the hard-muscular work to machines [4,23]. I40 creates new and sustainable business opportunities, shortening the time to market, and increasing production flexibility and efficient use of resources [24,25]. Finally, I40 adoption also creates positive externalities 
as it encourages safety and sustainable organizational practices outside of the organization adopting it [26].

On the other hand, scholars also stressed the negative impacts of I40. From an environmental point of view, organizations will employ more technologies and large data center within the organization exploiting more electricity and natural resources with a resulting increase in pollution [25]. Still, from a social point of view, since part of the activities_including decision making-passes from the workforce to machinery, I40 may eliminate several job roles $[5,27,28]$.

\subsection{Sustainability in Industry 4.0}

There is an initial understanding of the relationships between I40 and sustainability. Table 1 shows the details of a literature search we performed over the SCOPUS database of indexed scientific publication to review literature discussing the sustainability of I40. To enlarge the number of potential sources found we also included the keywords internet of things, smart factories, and cyber-physical systems (and their variations) in the query since researchers often used them as a synonym of I40 [29]. We also included in the review relevant articles cited from the literature sources found. Still, we exploited Web of Science functionality to find recently-published articles that cite the publications within the initial dataset [30].

Table 1. Literature search for sustainability and I40.

\begin{tabular}{cc}
\hline Item & Description \\
\hline Source & SCOPUS database \\
Query & $\begin{array}{r}\text { TOPIC: “industry 4.0” OR “internet of thin*” OR “smart factor" } \\
\text { OR “cyber physical system”" AND “sustainability” } \\
\text { Refined by: LANGUAGES: (ENGLISH), Subject Area: Business, } \\
\text { Management and Accounting, Source Type: Journals }\end{array}$ \\
\hline Hits & 34 \\
\hline Papers retained after: & 9 \\
- Title and abstract selection & 6 \\
- Full-text selection & 16 \\
\hline
\end{tabular}

The review portrayed an embryonal stage regarding knowledge of the topics with 16 literature sources selected [31-34]. A primary limitation in the literature sources is that few empirical studies targeted the sustainability impacts of I40 on the TBL [10,35]. Moreover, due to the novelty of these technologies, several studies focused on individual technologies of I40, and not on the overall cyber-physical system [27]. Finally, these investigations described more technical features of these technologies rather than their organizational impacts [36]. Five elements emerge from empirical studies of sustainability of I40.

With regards to the economic perspective of TBL, several studies report I40 leads to improvement concerning efficiency and effectiveness through new way for producing goods and optimization of the supply chain. Organizations using sensors in the assembly line improve economic sustainability through improved inventory management and warehouse management [37]. There is a consensus stating that IoT applications improve the efficiency and effectiveness of the supply chain management reducing the inventory inaccuracy and the time to market [38-40]. Data produced by I40 are mined to gather information for improving the product manufacturing life cycles and eventually the economic performance of the industry [41]. Thus, I40 strengthens managerial decision-making providing improved analytics capabilities of organizational phenomena.

The optimization of technical efficiency is related in the literature to the economic dimension of I40 [42,43]. I40 adoption can improve economic performance by employing predictive analysis and 
predictive maintenance, which eventually help organizations in reducing errors and defects through the assembly line [22].

With regards to the environmental perspective, the core aspect is the energy efficiency resulting from the capability to analyze and predict production performance, and of balancing energy consumption with the actual needs of the organization [42]. I40 enabled energy monitoring application, which led to energy efficiency and the reduction of $\mathrm{CO} 2$ emissions [6]. Energy savings also positively impact productivity within the organization [44].

One source cites the re-use of materials in a remanufacturing process enabled by IoT applications. The data produced by the IoT sensors are analyzed with a mathematical model to achieve costs reduction and to manage the remanufactured resources dynamically [45].

Finally, with regards to the impact on the social dimension, literature cites the creation of a safer workplace. A safer workplace is a consequence of the reduction of safety incidents and the increased morale of the employees [37,41].

\subsection{State of the Art and Gaps in the Studies of Sustainability in Industry 4.0}

Table 2 summarizes the current state of knowledge on the sustainability of I40. The literature so far shows how I40 supports the individual dimensions of the TBL. No empirical studies found evidence of simultaneous support to the three dimensions of the TBL, and this is a requirement for organizations willing to act sustainably $[29,46,47]$. Furthermore, few studies strived to investigate the relationships among the three dimensions of the TBL without reaching a consensus [48-50].

Table 2. I40 application and the supported sustainability dimensions.

\begin{tabular}{|c|c|c|c|}
\hline \multirow{2}{*}{ Authors } & \multicolumn{3}{|c|}{ TBL Dimensions } \\
\hline & Economic & Environmental & Social \\
\hline Goyal et al., 2016 & $\begin{array}{l}\text { Inventory management to } \\
\text { reduce inventory inaccuracy }\end{array}$ & & \\
\hline Cui et al., 2017 & $\begin{array}{l}\text { Supply chain management to } \\
\text { improve the efficiency } \\
\text { and effectiveness }\end{array}$ & & \\
\hline Lee et al., 2017 & $\begin{array}{l}\text { Warehouse management system } \\
\text { to improve productivity }\end{array}$ & & $\begin{array}{c}\text { Increase of employee } \\
\text { morale }\end{array}$ \\
\hline Reif et al., 2009 & $\begin{array}{l}\text { Picking System to } \\
\text { improve efficiency }\end{array}$ & & \\
\hline Zhang et al., 2018 & Real-time scheduling systems & Reuse of the materials & \\
\hline Shahbaz et al., 2012 & $\begin{array}{c}\text { Data mining to } \\
\text { improve the product } \\
\text { manufacturing life cycles }\end{array}$ & & \\
\hline Shin et al., 2014 & $\begin{array}{l}\text { Analytics model to maintain } \\
\text { technical efficiency }\end{array}$ & $\begin{array}{l}\text { Analytics model to predict } \\
\text { energy consumption }\end{array}$ & \\
\hline Thiede et al., 2018 & $\begin{array}{l}\text { Continuous energy monitor } \\
\text { reduces energy costs }\end{array}$ & $\mathrm{CO}_{2}$ Reductions & \\
\hline Lee et al., 2013 & $\begin{array}{l}\text { Predictive analysis to reduce } \\
\text { production mistakes }\end{array}$ & & \\
\hline Yuan et al., 2017 & $\begin{array}{l}\text { operational agility, improvement } \\
\text { of competitiveness }\end{array}$ & & $\begin{array}{l}\text { Reduction of safety } \\
\text { incidents }\end{array}$ \\
\hline Kembro et al., 2017 & $\begin{array}{c}\text { Improving warehouse } \\
\text { operations }\end{array}$ & & Safety workplace \\
\hline Liang et al., 2018 & Improving productivity & Energy saving & \\
\hline
\end{tabular}

In the literature discussing the sustainability of I40, we observed three individual trajectories of sustainability of I40 applications (see Figure 2). The impact over the economic dimension of the TBL is the result of improved process flexibility and efficiency, which in turns improves the economic 
performance. The trajectory over the environmental dimension of the TBL instead leverages on the improved quantity and granularity of data produced by the digital technology which improves the sustainable use of resources. Finally, the trajectory over the societal dimension of the TBL leverages increased automation thanks to the use of robotics and digitally connected pieces of machinery which create better labor conditions.

Trajectory

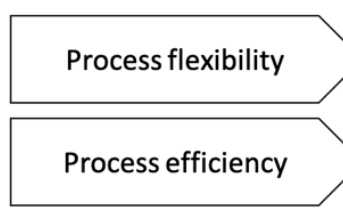

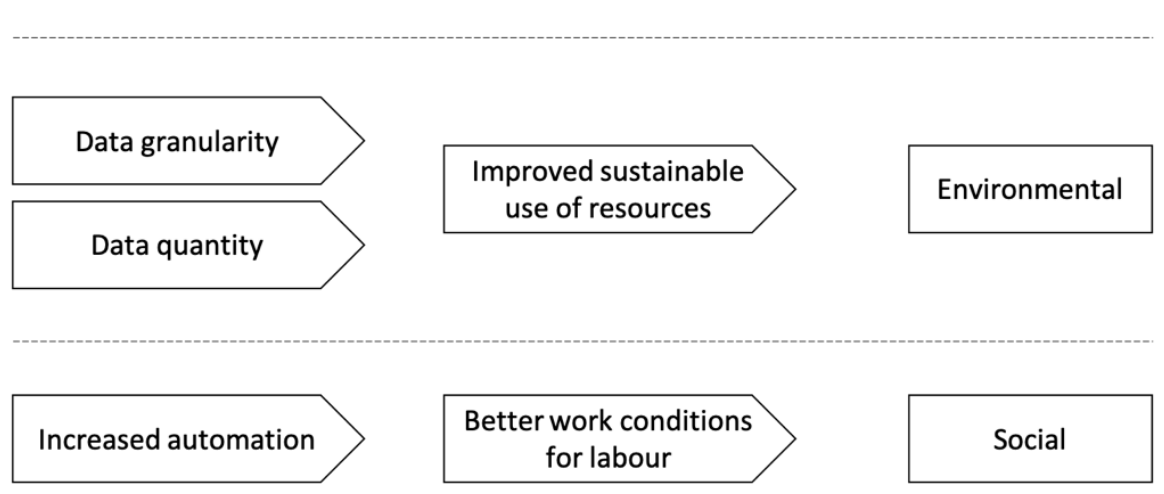

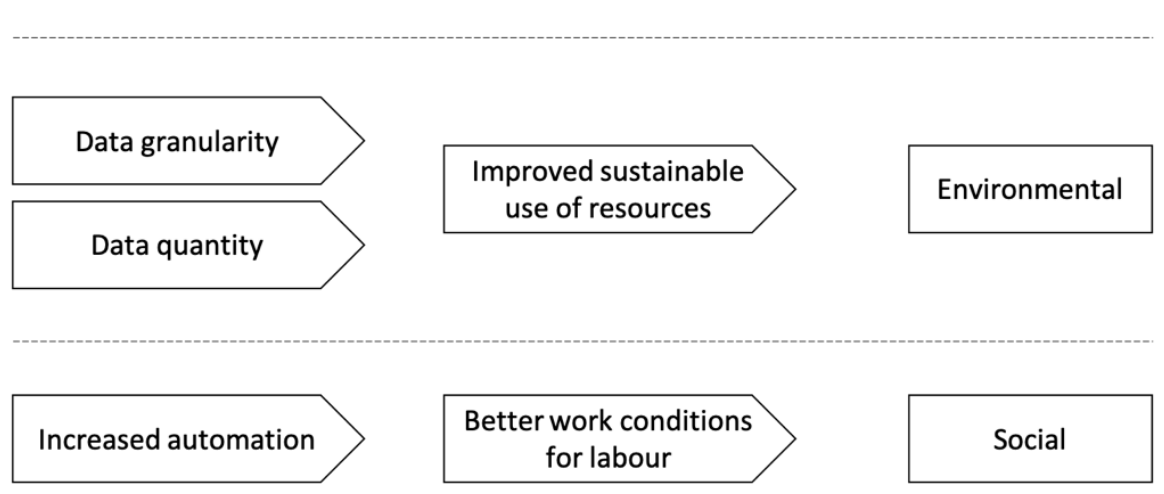

Economic

TBL dimension

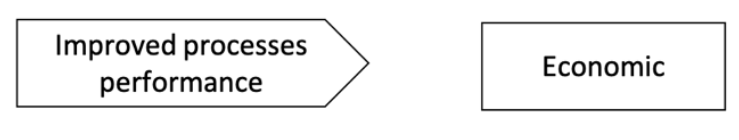

Figure 2. Trajectories of sustainability of I40 explored by the literature.

\section{Research Design}

This study aims to investigate whether the adoption of I40 contributes to all the three levels of sustainability and to investigate how the different dimensions of the triple bottom line interact consequent to its adoption.

The paper presents a single case study analysis of a manufacturing company in the ceramic industry [51]. The case is chosen as a revelatory one, as the company in question is the first mover in the adoption of I40 in its competitive domain. Second, the I40 adoption within the company coexists with the traditional production line which works in synergy with the new line. Furthermore, the same case was analyzed before from the perspective of environmental sustainability and economic sustainability [14]. In this research, we complemented the knowledge acquired collecting data on the I40 adoption and further investigating the three dimensions of sustainability.

The case study triangulates different data sources. We collected semi-structured interviews with the chief executive officer (CEO) and the chief production officer (CPO) following the track indicated in Table 3. Guided by the CPO, we also performed observations of the production line and had the possibility of observing operations of smart machines, control systems, and activities performed by workers on the line. During the observation, we also interviewed workers on the production line, and in the R\&D department, following the questions indicated in Table 3. We compiled field notes after the observations, which we added to the data we analyzed. We made use of secondary data in the form of official balance statements of the company and newspaper articles providing information on the economic performance of the firm. Finally, we also used the data obtained from the previous analysis on the same case unit to perform a triangulation improving the validity of the analysis and reducing subjectivity in empirical evidence $[52,53]$. 
Table 3. Interview track.

\begin{tabular}{c} 
Questions \\
\hline Interviewee \\
Management (CEO and CPO) \\
$\begin{array}{c}\text { Type and extensions of adoption of I40 technologies } \\
\text { Motivations and conditions triggering the adoption } \\
\text { The sequence of actions performed during the adoption } \\
\text { Consequences for the production processes after the adoption of I40 } \\
\text { Economic benefits of the I40 adoption } \\
\text { Environmental impacts of the I40 adoption } \\
\text { Social impacts of the I40 adoption }\end{array}$ \\
Organizational dimensions: number of employees, years of activity, \\
turnover level \\
Planned future adoption of I40 technologies \\
Workers $\quad \begin{array}{c}\text { Type and nature of the work performed in the company } \\
\text { Experience (if any) on the production process before I40 adoption } \\
\text { Benefits for the worker after the I40 adoption } \\
\text { Changes in working conditions before and after the I40 adoption } \\
\text { Personal awareness of the benefits of I40 adoption } \\
\text { Potential threats or risks in the I40 assembly line }\end{array}$ \\
\hline
\end{tabular}

We collected all the data sources in a single research database which we coded following the guidelines for the validity and reliability of qualitative inquiry $[54,55]$. The analysis was performed to identify first the dimensions of the TBL touched by the innovation processes of the organization. Second, we searched for interactions among the individual TBL dimensions, eventually identifying trajectories of interactions among them.

\section{Case Description}

The unit of analysis is a manufacturing company of the sanitary ceramic industry. The ceramic industry shows, on average, low levels of innovativeness, low technological level of products, and resorts massively to artisan processes [14]. Production presents low efficiency, produces much waste, and has a product defect rate higher than the average of other industries. Furthermore, the industry consumes a prodigious amount of energy, whose costs sum up to three percent of the annual turnover.

Within this landscape, our unit of analysis is a medium-sized organization attentive towards environmental sustainability and innovation in the product and process. It is working within a cluster of ceramic producers, and it is in the top three most significant companies in the cluster. In five years, the unit switched from a traditional assembly line to a smart factory design making use of IoT technologies, robotic arms, automatic forklifts, mechanical arms activated by people, and control information systems. The organization sided the new I40 assembly line to the traditional process, and still uses it for products whose demand level does not justify the high fixed costs of the I40 assembly line.

The production process consists of three phases: primary, secondary, and support. The primary phase encompasses all the activities needed to prototype and produce the goods. This phase ends with the baking of the product. The secondary phase is represented by the reprocessing of the product in case of mistakes; namely, to avoid impurities in the enamel. The support phase refers to the preparation of the product for packing, and eventual shipment, and the disposal of waste produced by the process. The unit uses I40 technologies in all three phases.

\subsection{Process of Adoption of the Industry 4.0}

The management of the organization decided to adopt I40 technologies to innovate the way they produce ceramics. The unit faced the competition of companies that moved their production to low labor cost countries. Consequently, the unit decided to respond to such competition on price with the increase of quality in the products. The adoption of I40 technology for the assembly line was deemed necessary to reduce the defect rate of products and to increase the quality. 
The innovation first required the redesign of the physical factory layout, as the I40 assembly line requires more space due to the use of several large-sized pieces of machinery. Then the factory was equipped with autonomous machines-like self-driving forklifts, robotized arms, and fully automatic conveyors - to produce products and move them from one phase to the other. In the end, all the machines were interconnected in a cyber-physical system and governed by a control information system that keeps track of the data produced by the assembly line and allows the company to manage the production process flexibly.

The unit anticipated the innovation project to the workers, and all employees attended vocational training courses to learn how their jobs would have changed following the adoption of these technologies. The employers' reaction to the adoption of the I40 innovation project was positive.

\subsection{Level of Current Adoption of Industry 4.0}

The unit has a fully integrated assembly line in which the intervention of humans on the most massive phases of production is minimal. The unit digitally traces the complete production process. The traceability data concerns the lead time, the machines that processed the product, and the workers controlling or operating the machines.

The I40 adoption also contributed to the digitalization of the design phase of the products. The organization started to use CAD to develop new product prototypes. It has created an internal research center that is continuously experimenting with materials and production steps to explore improvements in the way of producing ceramics and to try to reduce the defect rate of products even further. Still, the $\mathrm{CPO}$ announced that the organization is planning to use 3D printings to improve the design phase making prototyping and testing more efficient and sustainable.

Through the assembly line, different kinds of robots take on the hard work into the process, and workers act as supervisors. The semi-finished and finished products are placed on shelves and moved by autonomous fork trucks through the different steps of the assembly line, eventually into the warehouse. If the workers mark the part as defective or damaged, the trucks deliver it to a secondary phase. Workers use their knowledge in the production of ceramics to suggest new settings for the machine to improve the process and the quality of the product.

The unit still has a traditional assembly line in use where the workforce crafts the goods using mechanical machinery (before the baking phase), human drivers transport semi-finished and finished products on traditional forklifts. The traditional assembly line is in place for two purposes. First of all, the unit uses it for products with a small demand, for which the fixed costs of the integrated assembly line would be too detrimental for the final price. Second, it is used to train workers in the ceramic production process and to increase their expertise in the technical aspects of the process itself. Workers are then moved from the traditional to the integrated assembly line when they acquired enough knowledge of ceramic production so that they can contribute to improving the process and product.

\subsection{Results Achieved}

This section presents the pieces of evidence on the results achieved by the company following the adoption of I40 technologies. Following the dimensions of the triple bottom line, we distinguish between social, environmental, and economic impacts.

\subsubsection{Economic Impact}

The I40 adoption impacted the ceramic organization positively. The balance sheets show a negative trend from 2011 to 2013. In the same period, the staff decreased by about 30 employees. From 2014 to 2017, the balance sheet showed an increasing EBITDA index (earnings before interest, taxes, depreciation, and amortization) by 30\% (see Table 4). Sales and net profit show the same trend. The number of the employees remained stable in the last years after the transition to I40. 
Table 4. Economic performance after the I40 adoption.

\begin{tabular}{cccccccc}
\hline Index & $\mathbf{2 0 1 1}$ & $\mathbf{2 0 1 2}$ & $\mathbf{2 0 1 3}$ & $\mathbf{2 0 1 4}$ & $\mathbf{2 0 1 5}$ & $\mathbf{2 0 1 6}$ & $\mathbf{2 0 1 7}$ \\
\hline EBITDA & $€ 8.035 .000$ & $€ 7.500 .000$ & $€ 6.100 .000$ & $€ 8.150 .000$ & $€ 11.300 .000$ & $€ 15.000 .000$ & $€ 13.000 .000$ \\
Sales & $€ 36.860 .000$ & $€ 35.495 .000$ & $€ 36.335 .000$ & $€ 39.293 .00$ & $€ 43.280 .000$ & $€ 48,585.000$ & $€ 47.480 .000$ \\
Net Profit & $€ 2.330 .000$ & $€ 2.032 .000$ & $€ 1.248 .000$ & $€ 1.590 .000$ & $€ 4.115 .000$ & $€ 6.293 .000$ & $€ 5.376 .000$ \\
Workers & 284 & 284 & 267 & 237 & 237 & 224 & 233 \\
\hline
\end{tabular}

Regarding improvement within the production processes, the organization increased production by $30 \%$ reducing the lead time and increasing the gamut of products offered to customers and their quality level. According to the CEO, the pursuit of the highest quality has always been at the center of the organizational strategy: these technologies allowed the organization to govern their production processes, creating more practical and enduring products with a refined design.

The substitution of human workers with autonomous robots which took over all the physical work also contributed to the reduction of defects and damaged products. Consequently, the unit has seen a reduction of defect rate in their products from $30 \%$ down to $9 \%$.

Lastly, following the adoption of the I40 the unit can thoroughly monitor and govern the entire production process: the tracking of the goods was ameliorated reducing the order inaccuracy. Information concerning the processes is continuously analyzed providing comprehensive reports on the status of the machinery and predictions regarding future production trends.

\subsubsection{Environmental Impact}

Concerning the production process, the unit reduced the consumption of energy, water, and raw materials. The production process intensively reuses materials and resources. The heat generated by the baking phase of the production cycle is re-used for the gradual cooling of the final product, reducing the energy consumption by the process. At the same time of the I40 adoption, the unit also installed solar panels to produce electricity. I40 technologies continuously monitor energy production and consumption.

The use of autonomous trucks to move products across the line reduced accidental damage of products which also reduced waste. The use of robots instead increased the precision of the steps performed during the production process, reducing the defect rate. The reduction of the defect rate contributed eventually to a reduction of waste materials, and the avoidance of extra energy costs for the necessary repair phase of damaged products. Defective products which cannot be repaired are reused to the maximum extent possible, either as supports for the baking phase of conformant products, or as raw materials in the same process, or as raw materials in the construction industry [14]. Furthermore, the new production process allowed the company to sharply reduce waste of chalk molds and metals (used now only on the traditional assembly line), and muds.

Thanks to the digitalization of the entire production process, the unit is more capable of designing and testing products. The environmental sustainability also goes outside the production process and the product and moves to the customer. The redesigned products do not contain pollutants and use fewer resources (i.e., water in sanitaryware) during their daily life usage compared to traditional products.

\subsubsection{Social Impact}

The traditional ceramic production process is labor-intensive, and workers have a significant risk of being injured or burned out by the exhaustive working conditions. The traditional process makes use of chalks, paint, enamel, and other dangerous materials which increase powders in the air. These working conditions are the cause of lungs diseases and other kinds of traumatic diseases and create conditions for accidents. Adding to this, due to the presence of an oven that bakes products up to a temperature of $1200{ }^{\circ} \mathrm{C}$, workers usually worked in a factory with high environmental temperatures. 
Following the I40 adoption, the heavy manual labor was transferred to the I40 machines, reducing the number of incidents, and increasing the satisfaction of workers. Furthermore, on the I40 line workers act as supervisors and need new competencies, skills, and knowledge which they acquire through period training and vocational courses concerning the management and problem-solving in the use of the I40 technologies. The organization could then defend the workers' positions, as many employees who possessed only artisan skills in the traditional production process remained in the company as operators. The availability of the traditional line also helps in transitioning workers to the new assembly line because they can be trained for the new production process while they retain their employment position. It also contributed to enriching duties of workers thanks to the extension of the manual work towards a dimension of knowledge necessary by the workers to instruct machines on how to operate the production to be more efficient and to avoid defects.

The I40 adoption contributed to separate all the dangerous health phases, such as the glazing process, which have been entirely automated. The workforce can now act next to the pieces of machinery, and far from dangerous phases, in a much safer environment.

Finally, the adoption of I40 transitioned a traditional manufacturing company into a knowledge-intensive company. Though the employment level slightly decreased during the past years (see Table 4), the composition of the workforce changed, and several knowledge-intensive positions entered the company. This is the case of designers and 3D operators who work at the design and prototype phase of the products and of researchers who work in the R\&D unit of the company. Also, daily work of staff on the assembly process embeds a level of knowledge as workers act as the primary driver of continuous fine-tuning and improvement of the I40 assembly line by observing the production process and the output, and by suggesting changes to the working logic of robots that leads to process improvements in terms of efficiency or quality.

Table 5 shows the most relevant interview excerpts for the aspects discussed in the case description.

Table 5. Interview excerpts.

\begin{tabular}{|c|c|c|}
\hline Topic & Source & Interview Excerpt \\
\hline $\begin{array}{l}\text { Commitment to contribute to the } \\
\text { local economy }\end{array}$ & CEO & $\begin{array}{l}\text { We decided to implement I } 40 \text { because we know how to } \\
\text { produce ceramics, and even because I was born here, and I } \\
\text { want to remain here with my factory and production. }\end{array}$ \\
\hline Details of I40 adoption & $\mathrm{CEO}$ & $\begin{array}{l}\text { We had the luck to have enough space, our partner prepared } \\
\text { the implementation of each technology thoroughly, and we } \\
\text { previously communicated to employees these changes. }\end{array}$ \\
\hline Improved workforce conditions & $\mathrm{CEO}$ & $\begin{array}{l}\text { Employees thanked us, heavy manual labor was the critical } \\
\text { issue of the factory, now their tasks have changed favorably. }\end{array}$ \\
\hline Improved workforce conditions & Worker 1 & $\begin{array}{l}\text { I worked here also before the new line. Before they installed } \\
\text { the energy recovery system on the oven, the internal } \\
\text { temperature was very high. The factory was hot. Working } \\
\text { here in summer periods was terrible. Now the temperature } \\
\text { is ok throughout the whole year. }\end{array}$ \\
\hline Increased production & $\mathrm{CEO}$ & $\begin{array}{l}\text { This I } 40 \text { application is the first in the ceramic industry. We } \\
\text { risked a lot, but now our production increased by } 30 \% \text {. }\end{array}$ \\
\hline $\begin{array}{l}\text { Integration among pieces of } \\
\text { machinery }\end{array}$ & $\mathrm{CPO}$ & $\begin{array}{c}\text { The mobile robot communicates with the mechanical arm; it } \\
\text { knows when the mechanical arm finishes creating the } \\
\text { sanitaryware and put it on a shelf. Then, it will take the } \\
\text { sanitaryware. }\end{array}$ \\
\hline New workforce skills & $\mathrm{CPO}$ & $\begin{array}{l}\text { We hired this young worker. Now he is working in the } \\
\text { traditional factory acquiring the necessary craft skills. Then, } \\
\text { after a preparation course, we will employ him in the new } \\
\text { factory as a supervisor. }\end{array}$ \\
\hline New workforce skills & Worker 2 & $\begin{array}{l}\text { I am supervising these four machines which are now } \\
\text { producing washbasins. The work I do now is less manual } \\
\text { and more mental. I can activate and deactivate the machine, } \\
\text { and I try to figure out if there is a better way to let it work }\end{array}$ \\
\hline
\end{tabular}


Table 5. Cont.

\begin{tabular}{|c|c|c|}
\hline Topic & Source & Interview Excerpt \\
\hline Additive Manufacturing & $\mathrm{CPO}$ & $\begin{array}{l}\text { We are designing the implementation of the 3D printing to } \\
\text { improve our production and our sustainability. }\end{array}$ \\
\hline Reuse of resources & $\mathrm{CPO}$ & $\begin{array}{l}\text { We reuse both the water and the heat. It is possible since the } \\
\text { two plants are very close. We also recycle damaged products. } \\
\text { We tried to recycle all that enters the production phase. }\end{array}$ \\
\hline New roles for workers & $\mathrm{CPO}$ & $\begin{array}{l}\text { Now, the worker is close to the mechanical arm. He knows } \\
\text { how to craft the product. In case of mistakes of the } \\
\text { mechanical arm, he can detect them and halt production. }\end{array}$ \\
\hline New workforce skills & $\mathrm{CEO}$ & $\begin{array}{l}\text { Only the employees know how to improve the processes, we } \\
\text { appreciate their feedback. }\end{array}$ \\
\hline New workforce skills & R\&D staff 1 & $\begin{array}{l}\text { I am making tests to figure out which are the best conditions } \\
\text { for baking the ceramic to improve the quality. } \\
\text { We will program the robots on the assembly line according } \\
\text { to the parameters I will find. }\end{array}$ \\
\hline Knowledge intense activities & CEO & $\begin{array}{l}\text { The experts of the research center currently measure the } \\
\text { material that we will employ in the next production process } \\
\text { using this small oven, which simulates the real oven. }\end{array}$ \\
\hline
\end{tabular}

\section{Discussing the Sustainability of Industry 4.0}

This section presents the benefits regarding the sustainability of the I40. We firstly describe all the impact on the TBL of the I40. Afterward, we show how the I40 support the three dimensions of the TBL.

\subsection{Industry 4.0 Impact on the Triple Bottom Line}

To evaluate the impact of I40 adoption on sustainability, we showed in Figure 2 the I40 trajectory that aims at supporting the TBL. Our analysis also confirms all the trajectories previously identified in the literature.

Regarding the economic dimension, the I40 adoption allowed to improve the production thanks to more efficient and flexible processes [22,43]. In our unit of analysis, I40 led both to an increase in the level of production, and the quality of the final product. The organization could then exploit the premium price on the market thanks to the high level of quality. The organization achieved much higher revenues and dealt with new market segments that are served by different products more aligned to specific consumers' needs. Accordingly, the improved economic sustainability positively influences the social dimension with higher paid taxes and the environmental dimension with increased efficacy concerning resources used by production processes.

Regarding the environmental dimension, our unit acted environmentally friendly-for instance, producing photovoltaic energy and reducing energy consumption-also before the I40 adoption. Though I40 does not directly contribute to environmental sustainability, it improves these practices thanks to increased data precision on continuous energy consumption monitoring [6,45].

Regarding the social dimension, our unit of analysis put the workforce in the center of the innovation. The workforce enjoyed I40 adoption both for a safer work-environment and for a less intense work-load. In line with the literature, this had a positive impact on accidents and worker burn out. However, in our case, I40 adoption also offered opportunities for enriching the jobs of the workforce, making the job more gratifying and less alienating. The workers are not just operators of robots. They are part of a continuous feedback system where they suggest how to improve the programming of machines to improve the processes and the products-the nature of the work in the production line has shifted towards a knowledge-intensive rather than labor-intensive tasks. This transformation is also evident by the R\&D capabilities that the unit built internally, exploited to improve products and processes continuously, and to improve product design and prototyping 
capabilities thanks to the use of CAD designers. Both the R\&D personnel and the CAD designers were not in staff before the I40 adoption.

Answering the first $R Q$, besides confirming the trajectories identified in the literature, we find that I40 offers the possibility to strengthen the social dimension of sustainability thanks to the shift from labor-intensive to knowledge-intensive tasks.

\subsection{Interactions between the TBL Dimensions in Industry 4.0}

In our case, the I40 application allowed the organization to support the entire TBL thanks to the shifts from a traditional manufacturing organization to a knowledge-intense organization. The three dimensions of the TBL are also supporting each other.

With regards to the interaction between the economic and the remaining dimensions, the I40 adoption allowed to improve the quality of products boasting a premium price on the market, with which organization contrasted competitors that are producing low-budget products. Accordingly, the I40 adoption avoided the delocalization in countries where the workforce has low wages, as well as safeguarding the environment with cleaner production.

The high quality levels reached by the production process need a continuous improvement of processes, which is made possible by the role of workers who are part of a socio-technical system which continuously supervises the production to suggest improvements. Such continuous commitment warrants continuous employment opportunities for workers in companies and sustains economic performance.

The continuous improvement on the end side is also addressed concerned with the environmental dimension by the support that I40 technology offers to reduce the impact on natural resources, with a more precise measurement of the materials used, while improving financial performance (Table 4). Such improved control over materials opens the opportunity for reuse of resources, recycling, and reduction through the production process, in turn also supporting economic sustainability.

Table 6 presents the drivers of I40 that support the TBL. Answering our second research question, the trajectories we found encompass a virtuous cycle where economic, social, and environmental sustainability support each other, with the latter positively influencing the former.

Table 6. I40 drivers support triple bottom line dimension.

\begin{tabular}{|c|c|c|c|}
\hline \multicolumn{4}{|c|}{ I40 driver support TBL Dimensions } \\
\hline I40 Driver & Economic Dimension & Environmental dimension & Social Dimension \\
\hline $\begin{array}{c}\text { More Efficient } \\
\text { Production and Higher } \\
\text { Quality Products }\end{array}$ & Contrasting competitors & $\begin{array}{l}\text { Reduction in usage of natural } \\
\text { resources }\end{array}$ & $\begin{array}{l}\text { Production plant based in } \\
\text { Italy; higher job satisfaction } \\
\text { and taxes paid }\end{array}$ \\
\hline I40 Workers & $\begin{array}{l}\text { Reduction of production } \\
\text { mistakes and accidental } \\
\text { damages }\end{array}$ & $\begin{array}{c}\text { Reduction in usage of natural } \\
\text { resources }\end{array}$ & $\begin{array}{c}\text { Knowledge-based task; } \\
\text { work environment safer; } \\
\text { workforce as the innovator }\end{array}$ \\
\hline Research Center & $\begin{array}{l}\text { Saved Energy and less } \\
\text { production waste }\end{array}$ & Prevent production mistakes & Workforce hired \\
\hline
\end{tabular}

Concluding and discussing the relationship between technology adoption and the TBL, in our case study, the use of I40 technologies supports the entire TBL with the three dimensions strictly related to each other. We condense this impact on two trajectories that explain how the three dimensions of sustainability interact in I40 adoption (see Figure 3). 


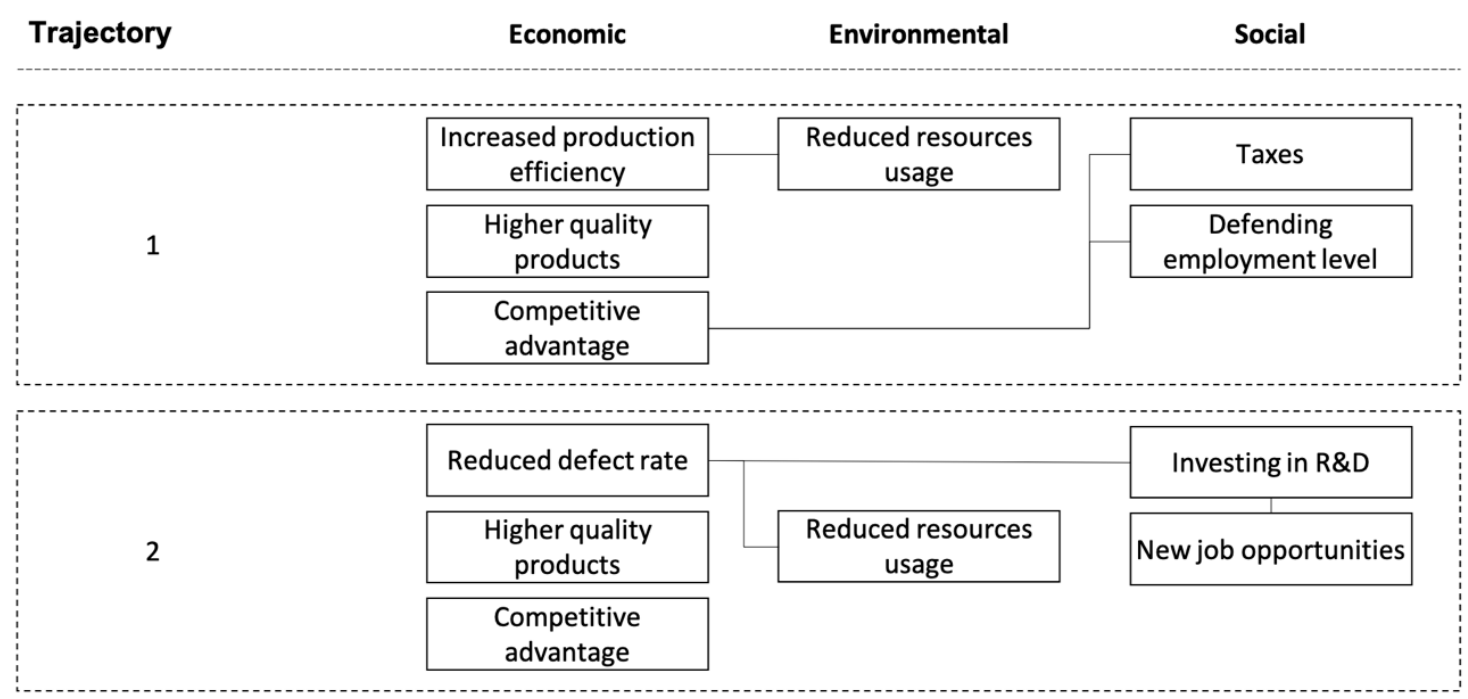

Figure 3. Trajectories connecting the three dimensions of the TBL in I40.

On the economic side, in our case, we found that I40 leads to increased production efficiency, higher quality products, and competitive advantage. This combination of economic factors is present in two trajectories.

In the first trajectory, the competitive advantage leads to increased social sustainability by defending the employment levels and paying more taxes on the value delivered. On the environmental side, the I40 adoption leads to reduced resources usage.

In the second trajectory, the investments in $R \& D$ produce new job employment opportunities supporting the social dimension of the TBL. These conditions enable the economic benefits highlighted, which eventually lead to reduced resource usage on the environmental side.

\section{Implications and Conclusions}

The exploration of how I40 application supports the three dimensions of the TBL was the primary motivation of our study. We presented an investigation regarding an I40 application in the ceramic manufacturing organization performing a single case study. We first highlighted the process of the I40 adoption, focusing on the changes within the production processes. Then, we investigated how I40 adoption supports the economic, environmental, and social dimensions of sustainability. Accordingly, we showed (Table 6) the improvement of the TBL defining how I40 application leads to them. We furthermore presented two trajectories of interaction among the three dimensions of TBL in the adoption of I40. In our study, we confirmed the relevance of the factors affecting the individual dimensions of the TBL, but we extended the understanding in the literature by describing how the different dimensions of the TBL interact following I40 adoption.

Though empirically validated, we based the results of our work on a single revelatory case study. Further research is required to study the impact of I40 adoption on the manufacturing industry by analyzing case units which differ regarding size and industry from the one studied here.

\subsection{Implications for Practitioners}

This study increases the knowledge and awareness concerning the TBL, which is an achievable goal even in practice. Indeed, we analyzed a case study of I40 adoption in a manufacturing context. This study can act as a guideline for similar organizations, which may aim to act sustainably through the benefits of I40 adoption regarding quality, improved use of resources, and continuous improvement.

Based on the results of the case, the first implication for practice concerns the central role of the workforce within the processes of innovation and sustainability. More knowledge is required in the workforce so that they can deal with these technologies and govern the production process in 
which they are used. Organizations aim to instill the systemic relationship between robotized pieces of machinery and human resources which leads to continuous improvements in the production process and the consequent improvement of the quality of the product.

Under this point of view, our case shows that the transition to I40 does not automatically imply the reduction of employment level. Furthermore, there is still the possibility to foresee continuous employment of workers who possess traditional artisan skills by turning them from operators of mechanical machines to supervisors and main agents of continuous improvement of the production process.

A second implication concerns the leadership and vision of the organization as drivers for I40 transition. In our case, the sustainable adoption of I40 technologies was guided by the CEO's objective to remain competitive on the market without delocalizing or moving to low-cost production processes. The transition has been driven by a purposeful internal innovation process which turned out to be sustainable as sustainable principles guided it.

\subsection{Implications for Researchers}

During the interviews, the management stressed the importance of pursuing sustainable goals since the design phase of the I40 adoption. Accordingly, this implies that the I40 adoption leads to the fulfillment of the TBL exclusively when organizations design it for this purpose [29]. This evidence even underpins the reason why a lack of empirical studies failed to support the TBL. Most of them put the attention exclusively on the economic dimension, underlining the impact on the remaining dimensions as a positive externality $[6,56]$. This raises the implication to study antecedents of I40 adoption to shed light on how they influence the actual adoption, and the impacts they have on the TBL.

In addition to this, supporting the social dimensions, the results of our work contradict the statement that I40 leads to technological determinism, allowing managers to lay off their workforce through the employment of leading-edge technology [27]. In our case, this initiative allowed the workforce to enrich its skills as well as getting improved environmental work conditions. Some scholars have advocated that I40 applications-especially robotics-are no longer to be considered socio-technical systems [57-59]. In our case, we instead confirm that human resources and robotic pieces of machinery are part of a sizeable socio-technical system, which also encompasses the knowledge dimensions of the work and the R\&D effort that are necessary to improve work conditions and product quality.

The last implication would be on the need to study the knowledge dimension of 140 application further. In our case, I40 adoption transforms a traditional manufacturing industry into a knowledge-intensive activity. The data generated by digital technologies support the benefits concerning sustainability. These data are the digital traces of actions performed by machines and human resources. However, these data could also constitute forms of knowledge spillovers that could flow to technology vendors and system integrators. Further research should investigate the interaction between the socio-material action of workers and the physical action of machinery and the consequences concerning knowledge production and leakage.

Author Contributions: All the authors contributed in the data collection and the case description for the case study. E.G.M. contributed performing the literature review of Industry 4.0 and Sustainability. A.M.B. contributed discussing the Sustainability of Industry 4.0. All the authors contributed to the formulation of implications for research and for practice, and all authors approved the manuscript.

Funding: This research received no external funding

Conflicts of Interest: The authors declare no conflict of interest. 


\section{References}

1. Boons, F.; Montalvo, C.; Quist, J.; Wagner, M. Sustainable innovation, business models and economic performance: An overview. J. Clean. Prod. 2013, 45, 1-8. [CrossRef]

2. Elkington, J. Cannibals with Forks-Triple Bottom Line of 21st Century Business; New Society Publishers: Stoney Creek, CT, USA, 1997.

3. Dao, V.; Langella, I.; Carbo, J. From green to sustainability: Information Technology and an integrated sustainability framework. J. Strateg. Inf. Syst. 2011, 20, 63-79. [CrossRef]

4. Kagermann, H.; Wolfgang, W.; Helbig, J. Recommendations for Implementing the Strategic Initiative INDUSTRIE 4.0; Work Group Acatech: Frankfurt am Main, Germany, 2013. [CrossRef]

5. Thoben, K.-D.; Wiesner, S.; Wuest, T. "Industrie 4.0" and Smart Manufacturing-A Review of Research Issues and Application Examples. Int. J. Autom. Technol. 2017, 11, 4-19. [CrossRef]

6. Thiede, S. Environmental Sustainability of Cyber Physical Production Systems. Procedia CIRP 2018, 69, 644-649. [CrossRef]

7. Herrmann, C.; Schmidt, C.; Kurle, D.; Blume, S.; Thiede, S. Sustainability in manufacturing and factories of the future. Int. J. Precis. Eng. Manuf. Green Technol. 2014, 1, 283-292. [CrossRef]

8. Sayar, D.; Er, Ö. The Antecedents of Successful IoT Service and System Design: Cases from the Manufacturing Industry. Int. J. Des. 2018, 12, 67-78.

9. Montreuil, B. Toward a Physical Internet: Meeting the global logistics sustainability grand challenge. Logist. Res. 2011, 3, 71-87. [CrossRef]

10. Kiel, D.; Muller, J.M.; Arnold, C.; Voigt, K. Sustainable Industrial Value Creation: Benefits and Challenges of Industry 4.0. Int. J. Innov. Manag. 2017, 21. [CrossRef]

11. World Commission on Environment and Development (WCED). Our Common Future; Oxford University Press: Oxford, UK, 1987.

12. Evans, S.; Vladimirova, D.; Holgado, M.; van Fossen, K.; Yang, M.; Silva, E.A.; Barlow, C.Y. Business Model Innovation for Sustainability: Towards a Unified Perspective for Creation of Sustainable Business Models. Bus. Strateg. Environ. 2017, 26, 597-608. [CrossRef]

13. Glavič, P.; Lukman, R. Review of sustainability terms and their definitions. J. Clean. Prod. 2007, 15, 1875-1885. [CrossRef]

14. Ruggieri, A.; Braccini, A.M.; Poponi, S.; Mosconi, E.M. A Meta-Model of Inter-Organisational Cooperation for the Transition to a Circular Economy. Sustainability 2016, 8, 1153. [CrossRef]

15. Dyllick, T.; Hockerts, K. Beyond the business case for corporate sustainability. Bus. Strateg. Environ. 2002, 11, 130-141. [CrossRef]

16. Littig, B.; Griessler, E. Social sustainability: A catchword between political pragmatism and social theory. Int. J. Sustain. Dev. 2005, 8, 65. [CrossRef]

17. Bansal, P. Evolving Sustainably: A longitudinal study of corporate sustainable development. Strateg. Manag. J. 2005, 26, 197-218. [CrossRef]

18. Norman, W.; Macdonald, C. Getting to the bottom of the triple bottom line. Bus. Ethics Q. 2004, 14, $243-262$. [CrossRef]

19. Carrillo-Hermosilla, J.; del Rio, P.; Könnölä, T. Diversity of eco-innovations: Reflections from selected case studies. J. Clean. Prod. 2010, 18, 1073-1083. [CrossRef]

20. $\mathrm{Xu}, \mathrm{X}$. From cloud computing to cloud manufacturing. Robot. Comput. Integr. Manuf. 2012, 28, 75-86. [CrossRef]

21. Braccini, A.M. La Generazione del Valore in una Organizzazione. Il Contributo della Tecnologia; Aracne Editrice: Roma, Italy, 2010.

22. Lee, J.; Lapira, E.; Bagheri, B.; Kao, H. Recent advances and trend in predictive manufacturing systems in big data environment. Manuf. Lett. 2013, 1, 38-41. [CrossRef]

23. Bogle, I.D.L. A Perspective on Smart Process Manufacturing Research Challenges for Process Systems Engineers. Engineering 2017, 3, 161-165. [CrossRef]

24. Lasi, H.; Fettke, P.; Kemper, H.G.; Feld, T.; Hoffmann, M. Industry 4.0. Bus. Inf. Syst. Eng. 2014, 6, $239-242$. [CrossRef]

25. Waibel, M.W.; Steenkamp, L.P.; Moloko, N.; Oosthuizen, G.A. Investigating the effects of Smart Production Systems on sustainability elements. Procedia Manuf. 2017, 8, 731-737. [CrossRef] 
26. Oesterreich, T.D.; Teuteberg, F. Computers in Industry Understanding the implications of digitization and automation in the context of Industry 4.0: A triangulation approach and elements of a research agenda for the construction industry. Comput. Ind. 2016, 83, 121-139. [CrossRef]

27. Kang, H.S.; Lee, J.Y.; Choi, S.; Kim, H.; Park, J.H.; Son, J.Y.; Kim, B.H.; Noh, S.D. Smart manufacturing: Past research, present findings, and future directions. Int. J. Precis. Eng. Manuf. Green Technol. 2016, 3, 111-128. [CrossRef]

28. Bonekamp, L.; Sure, M. Consequences of Industry 4.0 on Human Labour and Work Organisation. J. Bus. Media Psychol. 2015, 6, 33-40.

29. Piccarozzi, M.; Aquilani, B.; Gatti, C. Industry 4.0 in Management Studies: A Systematic Literature Review. Sustainability 2018, 10, 3821. [CrossRef]

30. Webster, J.; Watson, R.T. Analyzing the Past to Prepare for the Future: Writing a literature review. MIS Q. 2002, 26, 11.

31. Müller, J.M.; Voigt, K.-I. Sustainable Industrial Value Creation in SMEs: A Comparison between Industry 4.0 and Made in China 2025. Int. J. Precis. Eng. Manuf. Technol. 2018, 5, 659. [CrossRef]

32. Beier, G.; Niehoff, S.; Ziems, T.; Xue, B. Sustainability aspects of a digitalized industry-A comparative study from China and Germany. Int. J. Precis. Eng. Manuf. Technol. 2017, 4, 227-234. [CrossRef]

33. Gružauskas, V.; Baskutis, S.; Navickas, V. Minimizing the trade-off between sustainability and cost effective performance by using autonomous vehicles. J. Clean. Prod. 2018, 184, 709-717. [CrossRef]

34. Prause, G.; Atari, S.; Prause, G.; Atari, S. On sustainable production networks for Industry 4.0. Entrep. Sustain. Cent. 2017, 4, 421-431. [CrossRef]

35. Kamble, S.S.; Gunasekaran, A.; Gawankar, S.A. Sustainable Industry 4. 0 framework: A systematic literature review identifying the current trends and future perspectives. Process. Saf. Environ. Prot. 2018, 117, 408-425. [CrossRef]

36. Brettel, M.; Friederichsen, N.; Keller, M.; Rosenberg, M. Promoting work-based learning through industry 4.0. Int. J. Inf. Commun. Eng. 2014, 8, 37-44. [CrossRef]

37. Ben-Daya, M.; Hassini, E.; Bahroun, Z. Internet of things and supply chain management: A literature review. Int. J. Prod. Res. 2017, 7543, 1-24. [CrossRef]

38. Goyal, S.; Hardgrave, B.C.; Aloysius, J.A.; DeHoratius, N. The effectiveness of RFID in backroom and sales floor inventory management. Int. J. Logist. Manag. 2016, 27, 795-815. [CrossRef]

39. Cui, L.; Deng, J.; Liu, F.; Zhang, Y.; Xu, M. Investigation of RFID investment in a single retailer two-supplier supply chain with random demand to decrease inventory inaccuracy. J. Clean. Prod. 2017, 142, 2028-2044. [CrossRef]

40. Reif, R.; Günthner, W. An Augmented Reality supported Picking System. In Proceedings of the WSCG 2009, Plzen, Czech Republic, 2-5 February 2009.

41. Shahbaz, M.; Shaheen, M.; Khan, A.; Masood, A. Data mining methodology in perspective of manufacturing databases. Life Sci. J. 2012, 9, 13-22.

42. Shin, S.; Woo, J.; Rachuri, S. Predictive Analytics Model for Power Consumption in Manufacturing Predictive analytics model for power consumption in manufacturing. Procedia CIRP 2014, 15, 153-158. [CrossRef]

43. Yuan, Z.; Qin, W.; Zhao, J. Smart Manufacturing for the Oil Refining and Petrochemical Industry. Engineering 2017, 3, 179-182. [CrossRef]

44. Liang, Y.C.; Lu, X.; Li, W.D.; Wang, S. Cyber Physical System and Big Data enabled energy efficient machining optimisation. J. Clean. Prod. 2018, 187, 46-62. [CrossRef]

45. Zhang, Y.; Liu, S.; Liu, Y.; Yang, H.; Li, M.; Huisingh, D.; Wang, L. The 'Internet of Things' enabled real-time scheduling for remanufacturing of automobile engines. J. Clean. Prod. 2018, 185, 562-575. [CrossRef]

46. Kuhl, M.R.; Carlos, J.; Cunha, D.A. Relationship between innovation and sustainable performance. Int. J. Innov. Manag. 2016, 20, 1-17. [CrossRef]

47. Hansen, E.G.; Grosse-Dunker, F. Sustainability Innovation Cube-A framework to evaluate sustainability of product innovations. Int. J. Innov. Manag. 2009, 13, 683-713. [CrossRef]

48. Glavas, A.; Mish, J. Resources and Capabilities of Triple Bottom Line Firms: Going over Old or Breaking New Ground? J. Bus. Ethics 2015, 127, 623-642. [CrossRef]

49. Ozanne, L.K.; Phipps, M.; Weaver, T.; Carrington, M. Managing the Tensions at the Intersection of the Triple Bottom Line: A Paradox Theory Approach to Sustainability Management. J. Public Policy Market. 2016, 35, 249-261. [CrossRef] 
50. Lehtonen, M. The environmental—Social interface of sustainable development: Capabilities, social capital, institutions. Ecol. Econ. 2004, 49, 199-214. [CrossRef]

51. Yin, R.K. Case Study Research: Design and Methods, 4th ed.; Sage Publishing: Thousand Oaks, CA, USA, 1994.

52. Denzin, N. Sociological Methods: A Sourcebook, 5th ed.; Aldine Transaction: Piscataway, NJ, USA, 2006.

53. Walsham, G. Doing interpretive research. Eur. J. Inf. Syst. 2006, 15, 320-330. [CrossRef]

54. Corbin, J.; Strauss, A. Basics of Qualitative Research. In Techniques and Procedures for Developing Grounded Theory; SAGE Publications Inc.: Thousand Oaks, CA, USA, 2015.

55. Locke, K.D. Grounded Theory in Management Research; SAGE Publications: London, UK, 2011.

56. Lee, C.K.M.; Lv, Y.; Ng, K.K.H.; Ho, W.; Choy, K.L. Design and application of Internet of things-based warehouse management system for smart logistics. Int. J. Prod. Res. 2017, 7543, 1-16. [CrossRef]

57. Trist, E. The Sociotechnical Perspective: The Evolution of Sociotechnical Systems as a Conceptual Framework and as an Action Research Program; John Wiley and Sons: New York, NY, USA, 1981.

58. Fox, W.M. Sociotechnical System Principles and Guidelines: Past and Present. J. Appl. Behav. Sci. 2015, 31, 91-105. [CrossRef]

59. Asaro, P. What Should We Want from a Robot Ethic? Int. Rev. Inf. Ethics 2006, 6, 9-16.

(C) 2018 by the authors. Licensee MDPI, Basel, Switzerland. This article is an open access article distributed under the terms and conditions of the Creative Commons Attribution (CC BY) license (http:/ / creativecommons.org/licenses/by/4.0/). 